\title{
MAP2K2 Gene Rearrangement
}

National Cancer Institute

\section{Source}

National Cancer Institute. MAP2K2 Gene Rearrangement. NCI Thesaurus. Code C153257.

A molecular abnormality indicating rearrang ement of the MAP2K2 gene. 